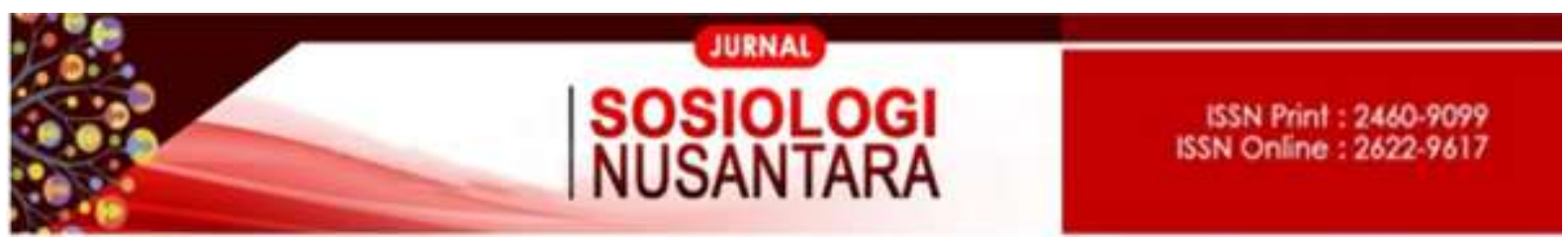

https://ejournal.unib.ac.id/index.php/jsn

DOI ://doi.org/10.33369/jsn.5.1.13-22

\title{
PENCEGAHAN TERORISME BERBASIS MASYARAKAT \\ DENGAN PEMBENTUKAN FORUM KOORDINASI PENCEGAHAN TERORISME DI TIGA PROVINSI
}

\author{
COMMUNITY-BASED TERRORISM PREVENTION \\ USING COORDINATION FORUM FOR TERRORISM PREVENTION \\ IN THREE PROVINCES
}

Andra Fahreza

fahrezaandra40@gmail.com

Magister Sumber Daya Manusia, Universitas Airlangga

\begin{abstract}
Abstrak
Penelitian ini menjelaskan mengenai konsep pencegahan kejahatan berbasis masyarakat, dalam kaitannya dengan pelibatan komunitas di dalam pembentukan Forum Koordinasi Pencegahan Terorisme (FKPT) di Provinsi Nusa Tenggara Barat, Aceh, dan Jawa Barat. Kebijakan pembentukan FKPT ini dilakukan oleh Badan Nasional Penanggulangan Terorisme (BNPT) sebagai lembaga pencegahan dan penanggulangan terorisme di Indonesia. Metode penelitian yang digunakan adalah metode penelitian kualitatif dengan pendekatan analisis data sekunder yang mana didapatkan dari laporan pelaksanaan kegiatan, dokumen/data dan jurnal ilmiah internasional mengenai terorisme, pembentukan Forum Koordinasi Pencegahan Terorisme (FKPT) dan program deradikalisasi yang dijalankan oleh BNPT di Indonesia saat ini. Dari hasil analisis, ditunjukkan bahwa pelibatan komunitas menjadi peran yang penting dalam pembentukan FKPT. Dalam pembentukannya, FKPT menggunakan pendekatan multi lembaga. Ditinjau dari konsep pencegahan kejahatan berbasis masyarakat, pembentukan FKPT merupakan mitra strategis BNPT. Didukung penerapan nilai kearifan lokal dimasingmasing daerah, hal ini diharapkan dapat menjadi strategi deradikalisasi yang efektif dalam upaya pencegahan terorisme di Indonesia.
\end{abstract}

Kata Kunci : Deradikalisasi, FKPT, Pencegahan Kejahatan Berbasis Masyarakat, Pendekatan Multi Lembaga, Terorisme.

\begin{abstract}
This research is tried to explain community-based crime prevention concept, in relation with involving the community in establishment of Coordination Forum for Terrorism Prevention (FKPT) in West Nusa Tenggara (NTB), Aceh, and West Java. FKPT establishment policy was conducted by The National Agency for Combating Terrorism (BNPT) which the purposes are to prevent and combat terrorism in Indonesia. The method used in this research is secondary data in which is obtained from implementation reports, documents and international journals about terrorism, the establishment Coordination Forum for Terrorism Prevention (FKPT) and de-radicalization by National Counterterrorism Agency (BNPT) nowadays. As the results of the analysis, the involving of the community becomes important role in FKPT
\end{abstract}


Pencegahan Terorisme Berbasis Masyarakat.....

establishment which is in practice, using a multi-agency approach. Refer to community-based crime prevention concept; FKPT establishment is the strategic partner of BNPT. Supported by implementation of local wisdom in each region, this policy is intended to be an effective strategy for de-radicalization program in order to prevent terrorism in Indonesia.

Keywords : Deradicalization, FKPT, Community-based crime prevention, Multi-agency Approach, Deradicalization, Terrorism

\section{PENDAHULUAN}

Terorisme merupakan salah satu bentuk kejahatan yang menjadi sorotan di dunia, karena tindakan tersebut menggunakan kekerasan atau mengancam dengan kekerasan terhadap masyarakat atau keamanan nasional apapun motifnya, sehingga menciptakan perasaan terancam dan ketakutan (Nusantara, 2016). Sejak berdirinya Negara Kesatuan Republik Indonesia (NKRI), Indonesia tidak pernah lepas dari ancaman teror dan banyak pihak menilai Indonesia mengalami ancaman terorisme sejak awal tahun 2000-an serta menjadi pusat perhatian dunia karena sebagai incumbent dan follower dalam bidang terorisme (Agus, 2014). Pada dasarnya, terorisme dipandang sebagai kejahatan luar biasa (Extraordinary Crime) dan merupakan suatu bentuk perang global, semacam perang dingin dengan peran pengganti yang berbeda. Bentuk teror sendiri dapat dilakukan dengan berbagai cara tindakan, diantaranya intimidasi dan ancaman, penganiayaan, penyanderaan, peledakan, pemboman, pembajakan, dan pembakaran. Pada masa kini, fenomena terorisme di Indonesia bukan merupakan hal yang asing lagi. Hal ini ditunjukkan dengan berbagai macam aksi teror yakni pada periode tahun 2000 sampai 2011, sebagai berikut :

Tabel 1. Jumlah kejadian terorisme di Indonesia dalam kurun Tahun 2000-2011

\begin{tabular}{cccc}
\hline Waktu & Tragedi & Korban Tewas & Korban Luka \\
\hline 1 Agustus 2000 & Kedutaan Negara Filipina & 2 & 21 \\
\hline 13 September 2000 & Bursa Efek Jakarta & 15 & 20 \\
\hline Desember 2000 & $\begin{array}{c}\text { 38 Gereja Seluruh Wilayah } \\
\text { Indonesia }\end{array}$ & & 240 \\
\hline 12 Oktober 2002 & Bom Bali 1 & 202 & 11 \\
\hline 25 Desember 2002 & $\begin{array}{c}\text { Restoran McDonald, } \\
\text { Makassar }\end{array}$ & 3 & 150 \\
\hline 5 Agustus 2003 & Hotel JW Marriot Jakarta & 12 & 115 \\
\hline 9 September 2004 & Kedutaan Negara Australia & 8 & 53 \\
\hline 1 Oktober 2005 & Bom Bali II & 26 & 28 \\
\hline 17 Juli 2009 & $\begin{array}{c}\text { Hotel JW Marriot \& Ritz } \\
\text { Carlton Jakarta }\end{array}$ & 7 & 110 \\
\hline 15 April 2011 & $\begin{array}{c}\text { Masjid Kantor Polresta } \\
\text { Cirebon }\end{array}$ & 1 (Pelaku) & \\
\hline
\end{tabular}

Sumber: "Deradikalisasi: Peran Masyarakat Sipil Indonesia Membendung Radikalisme" (Hikam, 2016) 
Tidak berhenti di situ saja, terdapat beberapa kasus terorisme di Indonesia juga berlanjut pada periode waktu 2015 sampai 2016, diantaranya: (1). April 2015, Bom di kawasan Permukiman di Tanah Abang, Jakarta; (2). Juli 2015, Bom di Mall Alam Sutera, Tangerang; (3). 28 Oktober 2015, Bom kembali meledak di Mall Alam Sutera, Tangerang; (4). November 2015, Bom di Jalan Raden Intan, Duren Sawit, Jakarta; (5). 14 Januari 2016, Bom di Sarinah, Thamrin, Jakarta; dan (6). 5 Juli 2016, Bom di Markas Kepolisian Reserse Kota Surakarta, Surakarta, Jawa Tengah.

Melihat banyaknya kejahatan terorisme, maka perlu dilakukan counter terrorism atau perang global melawan terorisme. Terdapat beberapa pendekatan, Ad'ha Aljunied (2011) menjelaskan ada dua pendekatan utama dalam perang global melawan terorisme. Pertama, pendekatan keras (Hard Approach), memerlukan keterlibatan fisik yang melumpuhkan rencana destruktif teroris, seperti pengeboman. Melalui legislatif, yudikatif dan eksekutif yang menunjukkan perang negara melawan terorisme, negara modern menggunakan metode seperti penangkapan, pengawasan, intelijen dan penahanan untuk melumpuhkan inisiatif para teroris. Kedua, pendekatan lunak (Soft Approach), merupakan upaya untuk merendahkan ideologi teroris melalui wacana kontra ideologi, terhadap ideologi radikal yang mendorong kekerasan politik.

Di sisi yang lain, atas banyaknya kejadian aksi teror dan terorisme di Indonesia, Pemerintah mengeluarkan instruksi Presiden Nomor 4 Tahun 2002 dalam rangka menanggulangi tindakan terorisme. Berdasarkan Keputusan Menteri Koordinator Bidang Politik dan Keamanan Nomor : Kep-26/Menko/Polkam/11/2002 dibentuklah Desk Koordinasi Pemberantasan Terorisme (DKPT) dengan tugas membantu Menteri Koordinator Bidang Politik dan Keamanan dalam merumuskan kebijakan bagi pemberantasan tindak pidana terorisme, meliputi : penangkalan, pencegahan, penanggulangan, penghentian penyelesaian, dan segala tindakan hukum yang diperlukan. Kemudian, berdasarkan Peraturan Presiden Nomor 46 Tahun 2010 dibentuk Badan Nasional Penanggulangan Terorisme (BNPT). Pendirian BNPT ini menandai dimulainya babak baru dalam metode penanggulangan terorisme yang mengedepankan metode soft approach.

Dapat dikatakan upaya pemberantasan terorisme tidak bisa dijalankan oleh BNPT tanpa partisipasi dan melibatkan banyak pihak. Berbagai pihak tersebut salah satunya adalah The Nusa Institute yang merupakan pihak yang bermitra dengan BNPT yang berasal dari elemen Lembaga Swadaya Masyarakat (LSM) dan berkepentingan dalam pemberantasan terorisme sesuai kemampuan dan kepentingannya masing-masing. Idealnya bekerja secara terkoordinasi untuk membentuk suatu sinergi (Golose, 2009). 
Pencegahan Terorisme Berbasis Masyarakat....

Dalam konteks pencegahan terorisme, masyarakat mempunyai andil besar di dalam lingkungan sosial dan menjadi entitas yang sangat vital. Masyarakat disini berperan memutus ideologisasi, mendeteksi keberadaan kelompok teroris, maupun dalam mengontrol tindak tanduk jaringan kekerasan ini. Partisipasi masyarakat dan lingkungan juga signifikan dalam mengungkap jaringan terorisme. Seperti misalnya, penangkapan jaringan Thorik di Tambora, Jakarta Barat. Penangkapan tersebut tidak lepas dari peran masyarakat untuk berpartisipasi membongkar jaringan terorisme. Selain itu, penangkapan Ridwan alias Ismail Cina yang berasal dari laporan masyarakat (Agus 2014).

Untuk merealisasikan pendekatan kepada berbagai elemen masyarakat, serta memacu partisipasi mereka dalam pencegahan terorisme, BNPT menampung aspirasi, informasi dari masyarakat dengan membentuk Forum Koordinasi Pencegahan Terorisme (FKPT) yang didalamnya melibatkan berbagai unsur komunitas masyarakat atau para stakeholders. Hal ini dikarenakan pemerintah (BNPT) mempunyai keterbatasan (Golose, 2009). Keterbatasan yang dimaksud meliputi : sumber dana, sumber daya manusia, dan teknologi.

Pembentukan FKPT di daerah juga merupakan salah satu implementasi strategi kontra-radikalisasi dan bertujuan untuk mensinergikan upaya pencegahan terorisme yang melibatkan seluruh unsur masyarakat dan pemerintah daerah dengan berbasiskan penerapan kearifan lokal guna menumbuhkan kesadaran dan kewaspadaan dini masyarakat yang mempunyai peran penting dalam pencegahan terorisme (Agus, 2014). Selain itu, FKPT merupakan forum non-partisan sehingga kehadirannya diharapkan mampu menjalin koordinasi yang terpadu dan integratif, serta merangkul seluruh elemen masyarakat. Koordinasi dan kerjasama antara pemerintah pusat, daerah, tokoh agama, tokoh masyarakat, TNI/Polri, dan seluruh organisasi kemasyarakatan, merupakan langkah nyata dalam upaya bersama mencegah berkembangnya terorisme. Menurut Wawan Purwanto (Pengamat intelijen), keberadaan FKPT ini akan membuat ruang gerak pelaku terorisme semakin sempit dan menjadi deteksi dini penting dalam pencegahan terorisme tersebut. Dengan demikian, adanya kerjasama erat antara pusat (BNPT) dengan daerah (FKPT) akan lebih memudahkan langkah antisipasi pencegahan terorisme.

Nelen \& Huisman (2008) menjelaskan bahwa terdapat dua faktor penunjang di dalam melakukan program pencegahan dan penanggulangan kejahatan yakni adanya faktor partisipasi dan kerjasama antara berbagai instansi/lembaga pemerintah dengan non pemerintah. Kedua faktor ini penting karena ketika melaksanakan program pencegahan kejahatan, khususnya pencegahan terorisme melalui pembentukan FKPT, dimana BNPT 
menjadi sektor terkemuka tidak bisa menjalankan program ini sendiri tanpa melibatkan kontribusi partisipasi aktif dan kerja sama dari instansi-instansi lintas sektoral baik dari pemerintah maupun non-pemerintah seperti unsur masyarakat dengan memberikan data maupun informasi yang berkaitan dengan pembentukan FKPT tersebut.

Berdasarkan beberapa hasil penelitian terdahulu yang menunjukkan bahwa pentingnya antisipasi pencegahan terorisme dari berbagai elemen masyarakat, maka Penulisan ini dimaksudkan untuk berfokus pada upaya pencegahan terorisme berbasis masyarakat dengan pelibatan masyarakat atau komunitas dari berbagai unsur didalamnya saat membentuk FKPT yang digagas oleh BNPT di tiga provinsi yakni Nusa Tenggara Barat, Aceh, dan Jawa Barat, hasil kerja sama BNPT dengan The Nusa Institute untuk mewakili 17 provinsi yang lain. Dengan pembentukan FKPT, dimana BNPT melakukan sinergitas dengan The Nusa Institute yang merupakan mitra pelaksana kegiatan pembentukan FKPT sebagai pencegahan terorisme berbasis masyarakat dan dilakukan dengan multi lembaga. Penelitian ini bertujuan untuk menjelaskan efektifitas pembentukan forum koordinasi pencegahan terorisme di Provinsi Nusa Tenggara Barat, Aceh dan Jawa Barat sebagai upaya pencegahan terorisme berbasis masyarakat.

Penelitian ini menjelaskan mengenai konsep pencegahan kejahatan berbasis masyarakat, dalam kaitannya dengan pelibatan komunitas di dalam pembentukan Forum Koordinasi Pencegahan Terorisme (FKPT) di Provinsi Nusa Tenggara Barat, Aceh, dan Jawa Barat. Sehingga akan membantu untuk memahami konsep pencegahan terorisme yang dilakukan di masyarakat.

\section{METODE PENELITIAN}

Metode penelitian yang digunakan adalah metode penelitian kualitatif dengan pendekatan analisis data sekunder. Menurut Sugiyono (2016) data sekunder adalah "Sumber data yang tidak langsung memberikan data kepada pengumpul data, misalnya lewat orang lain atau lewat dokumen". Data sekunder antara lain yaitu data yang diperoleh berasal dari data yang tidak secara langsung dari sumber data antara lain disajikan dalam bentuk data-data, tabel-tabel, diagram-diagram, atau mengenai topik penelitian. Data lain yang diperlukan dari topik yang akan dibahas, hasil di internet mengenai artikel-artikel, jurnal, dan laporan hasil dari pelaksanaan kegiatan yang dapat digunakan oleh penulis sebagai bahan perbandingan dengan penulisan yang dilakukan.

Dalam rangka memperoleh data sekunder, penulis mengumpulkan laporan pelaksanaan kegiatan, dokumen/data dan jurnal ilmiah internasional mengenai terorisme, 
Pencegahan Terorisme Berbasis Masyarakat....

pembentukan Forum Koordinasi Pencegahan Terorisme (FKPT) dan program deradikalisasi yang dijalankan oleh BNPT di Indonesia saat ini. Seluruh data sekunder yang diperlukan terlebih dahulu dikumpulkan oleh penulis yakni sebagai berikut: (1). Buku yang menjelaskan mengenai isu-isu terorisme seperti pengertian, bentuk dan lain sebagainya. Selain itu tentang deradikalisasi di luar lapas dan upaya strategi pencegahan kejahatan yang bisa dikaitkan dengan program deradikalisasi di luar lapas BNPT, (2). jurnal ilmiah, penelitian terdahulu mengenai program deradikalisasi yang telah dilakukan di beberapa negara di dunia, termasuk Indonesia. (3). Laporan pelaksanaan kegiatan dari The Nusa Institute (NI) mengenai koordinasi penangkalan dan rehabilitasi dibidang deradikalisasi, laporan tersebut berisi tentang pelaksanaan kegiatan pembentukan FKPT yang berhubungan dengan program deradikalisasi di luar lapas serta terdapat data/dokumen nota kesepahaman atau Memorandum of Understanding (MoU) antara BNPT dengan NI.

\section{PEMBAHASAN}

\section{Community-Based Prevention Dalam Pembentukan Forum Koordinasi Pencegahan Terorisme (FKPT)}

Schneider (2014) menjelaskan bahwa masyarakat mempunyai peran sentral melalui sosialisasi dari pendekatan "masyarakat yang lebih aman" untuk pencegahan kejahatan, yang memegang prinsip-prinsip berikut : Masyarakat adalah titik fokus dari pencegahan kejahatan yang efektif, masyarakat perlu mengidentifikasi dan menanggapi kebutuhan jangka panjang maupun pendek, upaya pencegahan kejahatan harus menyatukan individu dari berbagai sektor untuk mengatasi kejahatan, dan strategi untuk mencegah kejahatan harus didukung oleh seluruh masyarakat.

Komunitas atau masyarakat mempunyai peran dalam melakukan pencegahan terorisme dengan terlibat didalam pembentukan FKPT di tiga provinsi. Di dalam pelibatannya, masyarakat memiliki potensi dalam pencegahan terorisme. Kelly, et al., (2005) mengungkapkan bahwa masyarakat mempunyai peran dalam menentukan kebutuhannya sendiri saat melakukan aktivitas pencegahan kejahatan, masyarakat juga memberikan kontribusi. Pelibatan komunitas atau masyarakat dalam pembentukan FKPT, berbagai kelompok masyarakat berpartisipasi dengan melakukan koordinasi dengan pihak BNPT sebagai pihak dari pemerintah pusat yang membuat kebijakan pencegahan terorisme. Nantinya pemerintah pusat akan berkoordinasi dengan pemerintah daerah kemudian 
dikoordinasikan dengan berbagai elemen masyarakat seperti unsur dari tokoh pendidikan, tokoh adat, tokoh pemuda dan lembaga informal lainnya.

Disisi lain, berangkat dari asumsi bahwa warga negara didorong untuk memainkan peran utama dalam menjaga ketertiban dalam masyarakat dan karena itu harus didorong untuk menerima tanggung jawab lebih untuk pencegahan kejahatan (Schneider 2014). Seperti halnya yang terjadi di Provinsi NTB, bahwa masyarakat disana terlibat dan dipaksa untuk ikut dalam suatu diskusi yang beragendakan pembentukan FKPT, khususnya lembaga/tokoh adat NTB, karena FKPT ini pun berbasiskan kearifan lokal dengan mengharapkan adanya saling tenggang rasa, gotong royong, saling menghormati dan menghargai perbedaan yang ada. Hal itu yang akan menjadi kekuatan pencegahan terorisme di daerah, yakni dalam lingkup provinsi.

Kemudian di Provinsi Aceh sendiri, komunitas atau masyarakat yang terlibat dalam pembentukan FKPT seperti unsur dari pemerintah daerah, unsur tokoh agama, unsur tokoh masyarakat berpartisipasi didalamnya. Aceh terkenal dengan masyarakatnya yang religius dapat menjadi acuan dan kekuatan dalam menolak paham radikalisme dan terorisme di daerahnya. Hal tersebut tetap tergantung pada adanya sosialisasi dan penanaman normanorma serta nilai-nilai bersama di dalam masyarakat itu sendiri. Pelibatan unsur masyarakat tersebut untuk menjadi peserta dengan memberikan pandangan maupun informasi dalam pembentukan FKPT yang nantinya sebagai pengendali dan pencegahan kejahatan.

Provinsi Jawa Barat melakukan pembentukkan FKPT juga melibatkan berbagai unsur masyarakat, seperti pemerintah daerah, tokoh agama, tokoh masyarakat, tokoh pendidikan, tokoh pemuda/ormas, dan tokoh budaya. Pelibatan masyarakat tersebut mengindikasikan adanya peran sentral dari masyarakat itu sendiri dalam tujuan untuk melakukan pencegahan terorisme di daerah. Pihak-pihak seperti Kesbangpol, TNI, dan kejaksaan tinggi sebagai masyarakat formal juga dilibatkan seperti melakukan koordinasi dengan BNPT dan NI untuk penyediaan tempat acara pembentukan FKPT di Jawa Barat. Sedangkan unsur masyarakat seperti tokoh budaya setempat yang dilibatkan berperan sebagai tokoh yang dianggap mampu untuk memberikan pandangan di lingkungannya terkait dengan kearifan lokal, karena bisa dijadikan titik fokus pencegahan terorisme. 


\section{Strengths, Weaknesses, Opportunities, dan Threats (SWOT) Forum Koordinasi Pencegahan Terorisme (FKPT)}

\section{a. Strengths}

Mengenai strengths atau kekuatan dalam FKPT terletak pada kegunaannya sebagai penangkalan dan pencegahan terorisme dengan melibatkan berbagai unsur masyarakat yang ada di daerah. Terdapat juga kekuatan dari masing masing provinsi, misalnya untuk provinsi Nusa Tenggara Barat yang masih menganut kearifan lokal, memiliki tenggang rasa tinggi dan sifat gotong royong sehingga keterlibatan masyarakat menjadi kekuatan tersendiri. Provinsi Aceh masih melibatkan banyaknya unsur tokoh agama, provinsi yang menolak paham radikalisme dan terorisme sehingga lebih mudah bekerja sama dengan FKPT yang merupakan organisasi yang terbentuk untuk menghimpun aspirasi, informasi maupun laporan dari masyarakat dalam kontra-terorisme. Sedangkan Provinsi Jawa Barat yang merupakan daerah dekat ibukota maka dapat saling melakukan koordinasi dan kerja sama secara utuh, komprehensif dan berkesinambungan serta dilakukan secara bersama-sama.Kemudian nilai lain dari kekuatan organisasi ini ialah saling menghormati dan menghargai perbedaan yang digunakan sebagai perekat dalam rangka membangun bangsa. Selain itu, unsur-unsur stakeholders sebagai upaya pencegahan terorisme di daerah melalui adanya pembentukan FKPT ini dapat berjalan efektif dan sesuai tujuan bersama.

\section{b. Weaknesses}

Weaknesses atau kelemahan mengenai pembentukan FKPT pada masing-masing provinsi sebagaimana yang terjadi di provinsi Nusa Tenggara Barat terletak pada kurang rapinya koordinasi antar stakeholders, dan pola pikir masyarakat yang masih dipengaruhi kedaerahan. Sedangkan di Aceh, kelemahan terletak pada banyaknya tokoh agama yang cenderung menolak radikalisme dan pemahaman tentang terorisme. Jawa Barat memiliki kelemahan lain karena berasal dari banyak kalangan, maka masih ada perbedaan pandangan mengenai adanya FKPT dari peserta yang berasal dari anggota masyarakat dan tidak semua unsur mengutamakan peran aktif.

Selain kelemahan pada masing-masing daerah, terdapat juga kelemahan secara umum seperti masih adanya keterlambatan pembagian undangan bagi peserta yang akan berpartisipasi dan terdapat kesalahan dengan tidak adanya logo BNPT pada undangan tersebut. Terlihat dari laporan pelaksanaan kegiatan penangkalan dan rehabilitasi dibidang deradikalisasi yang bertujuan secara khusus untuk membentuk FKPT. Meskipun dinilai wajar dalam perbedaan pandangan atau pendapat, namun jika itu terjadi, maka akan mempengaruhi 
kinerja dari pembentukan FKPT itu sendiri, karena juga akan berpengaruh pada pola pikir kelompok masyarakat lainnya dalam menanggapi perbedaan itu.

\section{c. Opportunities}

Opportunities atau peluang dalam pembentukan FKPT pada tiga provinsi tersebut sama yaitu adanya peluang bagi masyarakat untuk terlibat dalam organisasi ini. FKPT yang menjadi mitra strategis dari BNPT akan memberdayakan kemampuan masyarakat untuk melakukan sistem deteksi dini munculnya kemungkinan aksi terorisme di daerah. BNPT yang telah memberikan fasilitas dengan membentuk FKPT di tiap daerah tentu menjadi peluang bagi semua unsur masyarakat untuk berpartisipasi aktif dengan memberikan pandangan maupun informasi. Tentunya peluang akan menjadi baik jika dilakukan koordinasi dan kerja sama dengan tiap unsur yang terlibat.

\section{d. Threats}

Threats atau ancaman dalam pembentukan FKPT pada tiga provinsi tersebut tidak lain ialah meningkatnya kecenderungan radikalisme, seperti adanya mantan narapidana teroris yang kembali menjadi teroris dan adanya propaganda melalui buku, majalah, internet dan lain sebagainya. Sehingga radikalisme menjadi ancaman nyata bagi seluruh komponen masyarakat termasuk dalam FKPT. Di sisi lain, tumbuh kembang kelompok teroris yang tidak disadari ditengah masyarakat terutama di lingkungan sosial dimana masyarakat itu tinggal.

\section{KESIMPULAN}

Pembentukan Forum Koordinasi Pencegahan Terorisme (FKPT) di tiga provinsi, yaitu Nusa Tenggara Barat, Aceh, dan Jawa Barat menjadi terobosan yang efektif, terkoordinasi dan berkesinambungan serta mempunyai peran penting dalam melakukan pencegahan terorisme di Indonesia dengan pelibatan berbagai elemen komunitas atau masyarakat. FKPT dibentuk berbasiskan kearifan lokal yang ada di tiap provinsi. Pendekatan multi lembaga dalam pembentukan FKPT merupakan solusi yang efektif dalam upaya pencegahan terorisme, dengan mendekatkan berbagai unsur masyarakat baik formal maupun informal di tiga provinsi. Pencegahan berbasis masyarakat dalam pembentukan FKPT juga melibatkan komunitas atau masyarakat yang saling berinteraksi melalui kegiatan diskusi, seminar, dan Focus Group Discussion (FGD).

Dalam pelaksanaannya di tiga provinsi, terdapat aspek partisipasi dan kerja sama, dua aspek tersebut dilakukan oleh berbagai stakeholders yang terkoordinasi dan komprehensif. Aspek partisipasi ditunjukkan dengan adanya peran dari berbagai unsur maupun pihak yang menjadi partisipan baik jadi peserta maupun narasumber dalam kegiatan yang secara khusus 
Pencegahan Terorisme Berbasis Masyarakat.....

bertujuan untuk melakukan pembentukan FKPT. Sedangkan aspek kerja sama ditunjukkan dengan adanya MoU atau nota kesepahaman, adanya Surat Perjanjian Kerja Sama (SPK) antara BNPT dengan The Nusa Institute sebagai lembaga mitra. Selain itu, menjalin koordinasi untuk menggalang kerja sama dengan berbagai pihak baik pemerintah daerah, tokoh masyarakat, tokoh pendidikan, tokoh adat, ormas Islam, organisasi kepemudaan, dan lain sebagainya.

\section{DAFTAR PUSTAKA}

Ad'ha Aljunied, Syed Mohammed. 2011. Religious Freedom in Malaysia's 'Islamic State': Comparisons with the Islamic State of Medina. Journal of Muslim Minority Affairs. 31(1) :113-23.

Agus, S. B. 2014. Merintis Jalan Mencegah Terorisme:( Sebuah Bunga Rampai). Semarak Lautan Warna.

Golose, Petrus Reinhard. 2009. Deradikalisasi Terorisme: Humanis, Soul Approach, Dan Menyentuh Akar Rumput. Yayasan Pengembangan Kajian Ilmu Kepolisian.

Hikam, Muhammad A. S. 2016. Deradikalisasi: Peran Masyarakat Sipil Indonesia Membendung Radikalisme. Jakarta : Penerbit Buku Kompas.

Kelly, Katharine D., Tullio Caputo, and Wanda Jamieson. 2005. Reconsidering Sustainability: Some Implications for Community-Based Crime Prevention. Critical Social Policy. 25(3) : 306-24.

Nelen, Hans and Wim Huisman. 2008. Breaking the Power of Organized Crime? The Administrative Approach in Amsterdam. Pp. 207-18 in Organized crime: culture, markets and policies. Springer.

Nusantara, Deradikalisasi. 2016. Perang Semesta Berbasis Kearifan Lokal Melawan Radikalisasi Dan Terorisme.

Schneider, Stephen. 2014. Crime Prevention: Theory and Practice. CRC Press.

Sugiyono. 2016. Metode Penelitian Dan Pengembangan (Research and Development/R\&D). Alfabeta: Bandung. 